\title{
Degree of realism (Fiction)
}

\section{AUTHOR}

Cordula Nitsch

\section{KEYWORDS}

entertainment, social reality, politics

\section{BRIEF DESCRIPTION}

The variable tries to capture the degree of realism of the fictional entertainment format. It was used in a systematization of TV series and movies that aimed to structure the field with regard to politics in fictional entertainment (Eilders \& Nitsch, 2014, 2015; Nitsch \& Eilders, 2014).

FIELD OF APPLICATION/THEORETICAL FOUNDATION The perceived degree of realism is usually considered in effect studies (as a moderating variable). However, it can also be applied to the fictional content and helps differentiating the innumerable fictional productions. It might be assumed that fictional entertainment formats with many references to social reality elicit other effects than TV series and movies that do not include aspects that are familiar to the audience from real-life.

\section{REFERENCES/COMBINATION WITH OTHER METHODS OF DATA COLLECTION}

$--$

\section{EXAMPLE STUDY}

Eilders \& Nitsch (2015)

INFORMATION ON EILDERS \& NITSCH, 2015

Authors: Christiane Eilders \& Cordula Nitsch Research interest: empirical classification of movies and TV series regarding their political intensity and degree of realism

Object of analysis: 114 movies and 98 TV series
Timeframe of analysis: 1990-2013

\section{INFORMATION ABOUT VARIABLE}

Variable name/definition: degree of realism

Degree of realism is indicated through four variables: realism 1 ) in terms of events, 2) in terms of characters, 3 ) in terms of time, and 4) in terms of places. Every indicator was coded on a scale ranging from 0 (no realism at all) to 3 (high degree of realism).

Realism in terms of events regards the degree to which the plot refers to real-life events (e.g., historical references, bank holidays). Realism of characters captures whether real actors or institutions are addressed in the plot. It was coded whether real characters played no role (0), a marginal role (1), a minor role (2), or a major role (3) in the TV series or movie. Realism in terms of time measures the time between the year of production and the year in which the fictional plot takes place. 0 was coded for plots located in periods deviating by more than 50 years from the production year, plots located in periods not overtly deviating from the production year were coded 3. Realism of places captures whether places are clearly identifiable. The highest score refers to plots that take place at particular locations on Earth, plots that take place in completely fictitious locations (such as Middle Earth in The Lord of the Rings) received the lowest score. Level of analysis: Film- bzw. Serienebene [level of movies/series]

Scale level: Nominal

Reliability: .87 (realism in terms of time: 1.0 , realism in terms of places: 0.9 , realism in terms of events: 0.86 and realism in terms of characters: $0.71)$ 


\section{1 Degree of Realism}

V1.3 Realitätsnähe der Zeit (RZ) (Bezugspunkt: Plot) [Realism in terms of time (RT) [Reference point: plot]]

Unter RZ wird codiert, wie weit das Produktionsjahr des Films/der Serie von der Zeit abweicht, die im Film/der Serie dargestellt wird. Es wird angenommen, dass Filme/Serien, die in der Vergangenheit oder Zukunft spielen, eine geringere Realitätsnähe haben. Filme/Serien, die in anderen Welten mit eigenen Zeitlinien spielen, sind ebenfalls nicht realitätsnah. Bei Filmen/Serien, die über längere Zeiträume hinweg spielen, wird das Jahr, in dem der größte Teil der Handlung spielt, herangezogen. Sollte dies nicht erkennbar sein, ist das früheste Jahr, das vorkommt, das Referenzjahr.

[For RT it is coded how far the production year of the movie/series deviates from the time the movie/series is set in. It is assumed that movies/ series which are set in the past or future are less close to (the viewers') reality. Movies/series that play in other worlds with their own timelines are also considered to have a low degree of realism. For movies/series that cover longer periods of time, the year in which most of the plot takes place is used. Should this not be recognizable, the earliest year the plot is set in, is used as the reference year.]

\section{$0=$ Keine Realitätsnähe}

Der Film/Serie spielt entweder in einem Jahr, das mehr als 50 Jahre (plus/minus) vom Produktionsjahr des Films/Serie abweicht oder in einer Welt mit anderer Zeitrechnung.

Beispiel: „Braveheart“ als Film, der im Mittelalter spielt und somit mehr als 50 Jahre vom Produktionsjahr 1995 abweicht.

$1=$ Geringe Realitätsnähe

Der Film/Serie spielt in einem Jahr, das zwischen 50 und 11 Jahren (plus/minus) vom Produktionsjahr des Films/Serie abweicht.

Beispiel: „Das Leben der Anderen“ als Film, der 1984 spielt und somit 22 Jahre vom Produktionsjahr 2006 abweicht.

\section{$2=$ Mittlere Realitätsnähe}

Der Film/Serie spielt in einem Jahr, das vom Pro- duktionsjahr maximal 10 Jahre (plus/minus) abweicht.

Beispiel: „Hotel Ruanda“ als Film, der 2004 gedreht wurde und im Jahr 1994 spielt.

\section{3 = Hohe Realitätsnähe}

Der Film/Serie spielt in einem Jahr, das vom Produktionsjahr durch keine sichtbare Verweise auf eine andere Zeit abweicht.

Beispiel: „Keinohrhasen“ als Film, in dem es keine erkennbare Abweichung von Produktionsjahr und der dargestellten Zeit gibt.

\section{REFERENCES}

Eilders, C., \& Nitsch, C. (2014). Politikvermittlung zwischen „Traumschiff“ und „The West Wing“: Ein Vorschlag zur Systematisierung von Fernsehserien [Political depictions between „Traumschiff“ and „The West Wing": A proposal for a systematization of TV series]. In M. Dohle \& G. Vowe (Hrsg.), Politische Unterhaltung - Unterhaltende Politik. Forschung zu Medieninhalten, Medienrezeption und Medienwirkungen (S. 138-162). Köln: Herbert von Halem.

Eilders, C., \& Nitsch, C. (2015). Politics in Fictional Entertainment: An Empirical Classification of Movies and TV Series. International Journal of Communication, 9, 1563-1587.

Nitsch, C. \& Eilders, C. (2014). Die Repräsentation von Politik in fiktionaler Unterhaltung. Instrument, Anwendung und Befunde zur Systematisierung von Filmen und Fernsehserien [The representation of politics in fictional entertainment. Instrument, application and results for a systematization of films and TV series]. Studies in Communication | Media, 3(1), 120-143. 